\title{
Meter-scale lateral heterogeneity of nitrate concentrations of groundwater in aquitards
}

\author{
Seiichiro IOKA*1 and Norio TASE*2
}

\begin{abstract}
The long-term protection of the world's groundwater resources partially depends on the ability of aquitards to retard the movement of natural and anthropogenic solutes, and hence, it is important to understand the processes controlling the distribution, transport, and attenuation of dissolved materials. Moreover, the consequences of increasing amounts of anthropogenic $\mathrm{N}$ circulating in groundwater is of concern, and the attenuation and transport processes of $\mathrm{NO}_{3}{ }^{-}$present in the groundwater in aquitards must be examined. We have investigated the lateral distributions of $\mathrm{NO}_{3}^{-}$concentrations in groundwater in an aquitard $(4 \mathrm{~m} \times 6 \mathrm{~m}$ area) at Tsukuba upland at a few meter-scales and attempted to identify the possible mechanisms for their heterogeneity; this, to our knowledge, is the first such study. High-resolution measurements were obtained using piezometers, and they revealed complex lateral $\mathrm{NO}_{3}{ }^{-}$heterogeneity. Large variations in the $\mathrm{NO}_{3}{ }^{-}$concentrations were found between groundwater samples from piezometers that were horizontally separated by a distance of as little as $2 \mathrm{~m}$. Although the mechanism of lateral $\mathrm{NO}_{3}{ }^{-}$heterogeneity in the aquitard remained unclear, we believe that the occurrences of biochemical reactions such as denitrification and other factors such as the spatial variability of $\mathrm{NO}_{3}{ }^{-}$transport play a role in it. This first study of the meter-scale lateral heterogeneity of $\mathrm{NO}_{3}^{-}$ concentrations of groundwater in aquitards provides new insights into the mechanisms of natural attenuation of $\mathrm{NO}_{3}{ }^{-}$in aquitards; further, our study also discusses difficulties in some of the upscaling approaches of the $\mathrm{NO}_{3}^{-}$natural attenuation zone in groundwater based on the data obtained from a small number of piezometers.
\end{abstract}

Key words: heterogeneity, nitrate, groundwater, aquitard

Introduction

Aquitards are low-permeability beds along aquifer systems, and they have significant influence on the groundwater quality of aquifer systems (Back, 1986; Van Stempvoort and van der Kamp, 2003). The long-term protection of the world's groundwater resources, especially their water quality, will depend in part on the ability of aquitards to attenuate and retard the migration of natural and anthropogenic solutes (e.g. Lei and Tase, 1986;
Ponzini et al., 1989; Rudolph et al., 1991; McMahon, 2001; Harrington and Hendry, 2005). Hence, it is important to understand the processes controlling the distribution, transport and attenuation of dissolved materials in aquitards worldwide.

In recent times, concerns regarding the consequences of increasing amounts of anthropogenic $\mathrm{N}$ circulating in the world's subsurface environments have been increasing (e.g., Otero et al., 2009; Reddy et al., 2009; Umezawa et al., 2009). The distribution, transport and attenuation processes of $\mathrm{NO}_{3}^{-}$in

* 1 North Japan Institute for Sustainable Energy, Hirosaki University 弘前大学北日本新エネルギー研究所

* 2 Graduate School of Life and Environmental Sciences, University of Tsukuba 筑波大学生命環境科学研究科 
groundwater at the watershed scale have been reported previously (e.g. Böhlke and Denver, 1995; Tesoriero et al., 2000; Böhlke et al., 2002; Tesoriero et al., 2007). In particular, several studies have attempted to examine the attenuation and transport processes of $\mathrm{NO}_{3}{ }^{-}$present in the groundwater in aquitards (Fujikawa and Hendry, 1991; Ernstsen, 1996; Robertson et al., 1996; Ernstsen et al., 1998; Eidem et al., 1999; McMahon et al., 1999; Rodvang and Simpkins, 2001; Jørgensen et al., 2004; Ioka and Tase, 2004a; Hansen et al., 2008). Further, a few studies have examined the heterogeneity of $\mathrm{NO}_{3}{ }^{-}$concentrations of groundwater in aquitards (Ernstsen, 1996; Robertson et al., 1996) however, to our knowledge, the meter-scale lateral heterogeneity of $\mathrm{NO}_{3}^{-}$concentrations in the groundwater in aquitards has not been investigated so far. Such an investigation is important because if no data is available on the local variations in the $\mathrm{NO}_{3}^{-}$concentrations in aquitards, it is difficult to develop an upscaling methodology for $\mathrm{NO}_{3}{ }^{-}$cycle models and $\mathrm{NO}_{3}{ }^{-}$attenuation zones in aquitards.

Hence, in this study, we have aimed to investigate the lateral distributions of $\mathrm{NO}_{3}{ }^{-}$concentrations in the groundwater in an aquitard in Tsukuba upland at a few meter-scales and to identify the possible mechanisms for their heterogeneity.

\section{Study plot description}

The study area was located in Tsukuba upland, which is approximately $15 \mathrm{~km}$ northwest of Kasumigaura (Fig. 1a, b). At study area, according to information obtained from farmers, inorganic fertilizers (N: P: K: 15: 15: 15; $200 \mathrm{~kg}$ per 10 a) are applied for three times from April to October in the lawn grown land. The study plot consisted of fallow soil; its land elevation was 22.50-22.75 m, whereas its area was $4 \mathrm{~m} \times 6 \mathrm{~m}$ (Fig. 2).

The alluvial aquifer-aquitard system in study area is composed of unconsolidated sediments of Quaternary age. The system in the study plot consists of four layers. The top layer is Younger Loam Formation comprised of volcanic ash soil (Unozawa, 1988). Beneath the Younger Loam Formation or Joso Clay was a sand and gravel layer. The hydraulic conductivity of the Joso Clay layer ranges from an order of $10^{-8}$ to $10^{-11} \mathrm{~m} / \mathrm{s}$ (Yasuhara et al., 1991) and from an order of $10^{-6}$ to $10^{-11} \mathrm{~m} / \mathrm{s}$ (Yuita et al., 2002). This sand and gravel layer had an underlying by silt and clay layer (Fig. 3). The hydraulic conductivity of the silt and clay layer was investigated by using the slug test (Hvorslev, 1951) and found to be ranging from an order of $10^{-9}$ to $10^{-10}$ $\mathrm{m} / \mathrm{s}$. In this study, the silt and clay layer acting as an aquitard has been investigated. The water table at the study plot is approximately 0.5 to $1.0 \mathrm{~m}$ below the land surface (Ioka and Tase, 2004b).

\section{Methodology}

The groundwater samples for this study were collected using piezometer nests installed 2.0, $2.5,3.0$, and $3.5 \mathrm{~m}$ below the land surface using a polyvinyl chloride (PVC) tube (inner diameter (ID): $2 \mathrm{~mm}$ ) and plastic syringes. The piezometer nests were constructed from commercially available PVC pipes having IDs of $40 \mathrm{~mm}$ and fitted with a drive point (Figs. 2 and 3). The sampling of groundwater was completed on August 28, 2003, October 24, 2003 and December 28, 2003. Unfiltered groundwater samples were taken for the field measurements of specific electrical conductivity (SEC) at $25{ }^{\circ} \mathrm{C}$ using an EC meter (Yokogawa Model SC82) and dissolved oxygen (DO) concentration using a DO meter (DKK-TOA, Model DO-24P) and for the laboratory measurement of alkalinity. Although DO concentration should always be measured either using an in situ probe or in a flow-through cell at the surface (Nielsen and Nielsen, 2006), in 
(a)

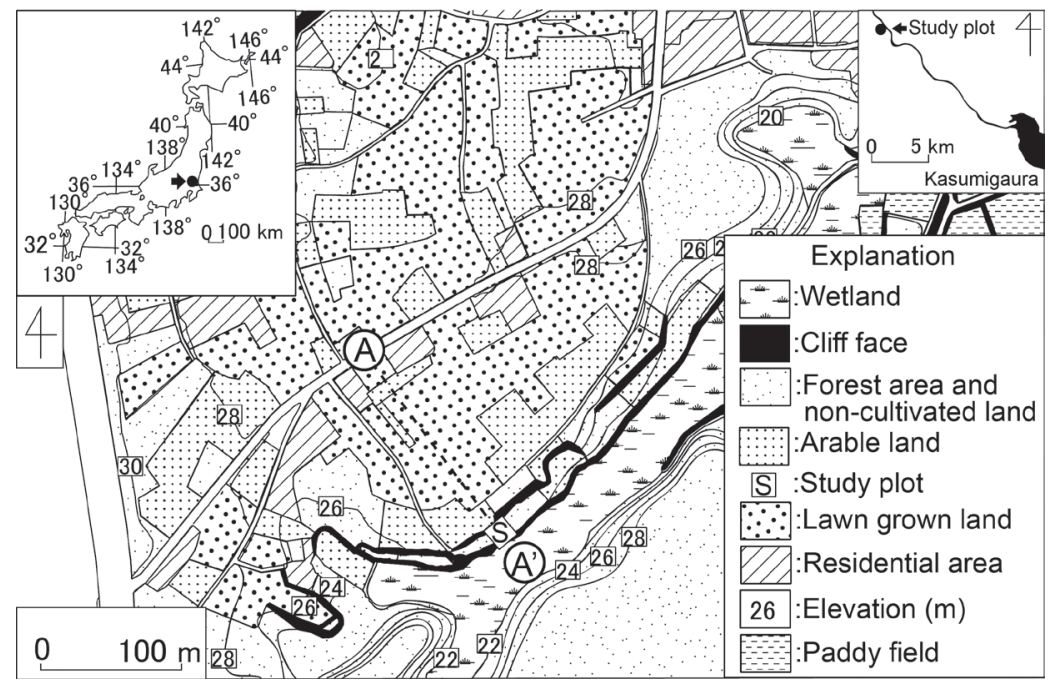

(b)

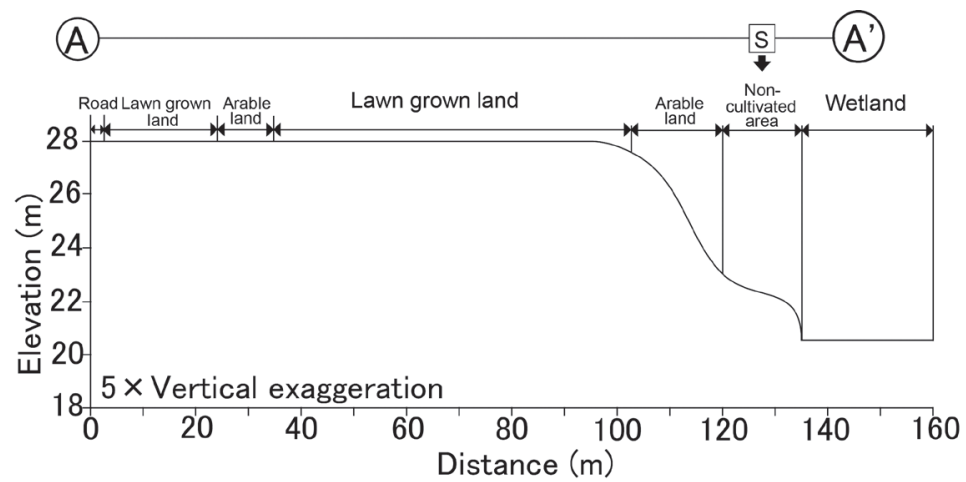

Fig. 1 (a), (b) Topography and land use in the study area (modified after Ioka and Tase, 2004a).

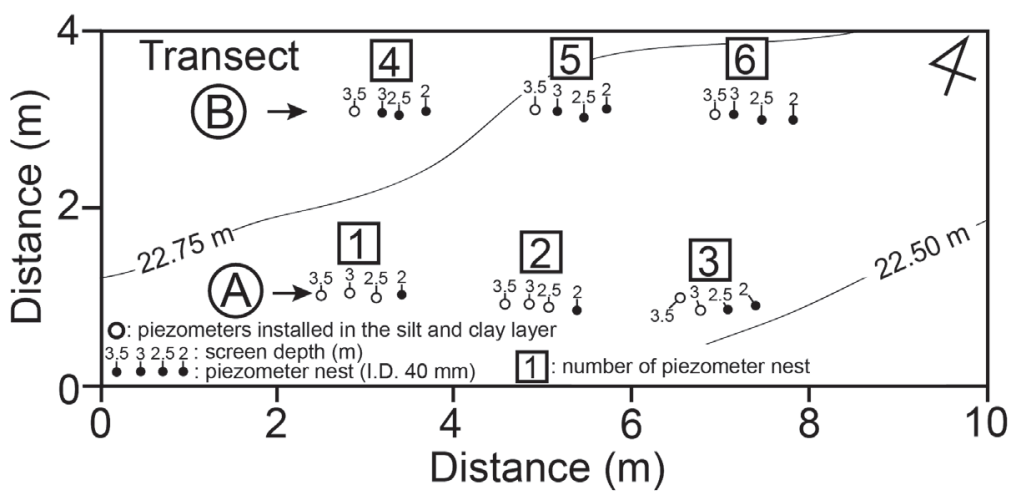

Fig. 2 Locations of piezometer nests at the study plot. Contour lines reflect topography at $0.25 \mathrm{~m}$ intervals. 


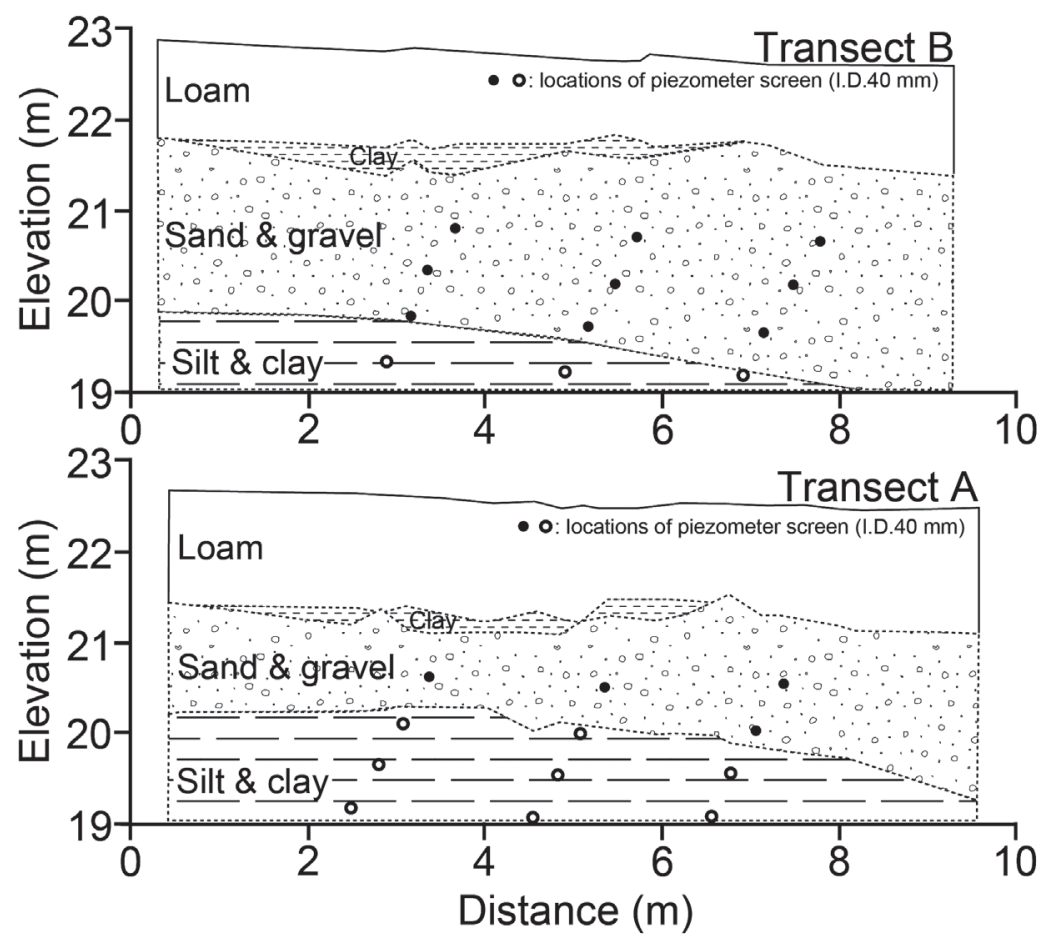

Fig. 3 Geology and piezometer screen distributions along two transects (locations shown in Figure 2). $\bullet$ : piezometers installed in the sand and gravel layer. $\bigcirc$ : piezometers installed in the silt and clay layer.

this study, the DO concentrations were measured in an open container, where there is an air-water interface. Hence, the DO concentrations in this report are not true values but approximate values and these approximate values of DO concentrations will be higher than the true values. Other samples were passed through cellulose acetate membrane filters $(0.2 \mu \mathrm{m})$ and used for anion analysis. Water samples for the determination of alkalinity and $\mathrm{NH}_{4}{ }^{+}$ concentration were collected in $100-\mathrm{mL}$ and $50-\mathrm{mL}$ polyethylene bottles, respectively, and those for anion analysis were collected in 24-mL glass vials.

The $\mathrm{NO}_{3}^{-}, \mathrm{NO}_{2}^{-}, \mathrm{Cl}^{-}$, and $\mathrm{SO}_{4}{ }^{2-}$ concentrations were analyzed with a QIC analyzer (Dionex) equipped with a Dionex AS4A IonPac column and an anion micromembrane suppressor (Dionex, Model AMMS- II). $\mathrm{NO}_{2}{ }^{-}$was detected only in the groundwater sampled from a depth of $3.5 \mathrm{~m}$ in the piezometer nest number 5 (Fig. 2) in October and December 2003. The $\mathrm{NO}_{2}^{-}$concentrations were 0.11 and $0.10 \mathrm{mg} / \mathrm{L}$, respectively. $\mathrm{NO}_{2}^{-}$was not detected in any other groundwater samples. Thus, $\mathrm{NO}_{2}{ }^{-}$concentrations are not shown in a figure. The $\mathrm{NH}_{4}{ }^{+}$concentrations were measured using an ion electrode (DKK, Multi-channel Ion Meter, Model IOL-40). Considering the linear relationship between the logarithms of $\mathrm{NH}_{4}{ }^{+}$concentration and the difference in measured voltage, we set the quantification limit of the ion electrode as 50 $\mu \mathrm{g} / \mathrm{L}$. The 82 and $62 \mu \mathrm{g} / \mathrm{L}$ concentrations of $\mathrm{NH}_{4}{ }^{+}$ were measured in groundwater samples obtained from a depth of $2.5 \mathrm{~m}$ in piezometer nest number 2 (Fig. 2) in August 2003 and a depth of $2.0 \mathrm{~m}$ in piezometer nest number 3 (Fig. 2) in December 2003, respectively. The $\mathrm{NH}_{4}{ }^{+}$concentrations in other groundwater samples were below the quantification 
limit. Thus, $\mathrm{NH}_{4}^{+}$concentrations are not shown in a figure. Alkalinity was measured by titration using 0.02- $\mathrm{N} \mathrm{H}_{2} \mathrm{SO}_{4}$ with methyl red and bromocresol green $(\mathrm{MR}-\mathrm{BCG})$ as the colorimetric indicator. The $\mathrm{HCO}_{3}{ }^{-}$concentrations were calculated from the values of alkalinity values.

\section{Results and discussion}

The contour lines of the hydraulic head (m), $\operatorname{SEC}(\mu \mathrm{S} / \mathrm{cm})$, and the $\mathrm{Cl}^{-}$concentration $(\mathrm{mg} / \mathrm{L})$ in piezometer nests (ID of $40 \mathrm{~mm}$ ) observed on August 28, 2003, October 24, 2003, and December 28, 2003 are presented in Figs. 4-6. The piezometer nests are divided into transects A and B (Fig. 2). The contour lines of hydraulic head revealed that the dominant direction of groundwater flow in both transects is horizontal in the sand and gravel layer and downward in the silt and clay layer; this implies that the aquitard is supplied with water from the sand and gravel layer in the upper layer. The downward groundwater flow was observed from a depth of $2.5 \mathrm{~m}$ to $3.5 \mathrm{~m}$ in transect $\mathrm{A}$ and from a depth of $3.0 \mathrm{~m}$ to $3.5 \mathrm{~m}$ in transect $\mathrm{B}$. The contour lines of the SEC and $\mathrm{Cl}^{-}$concentration in both transects indicated that the values ranged from approximately 250 to $310 \mu \mathrm{S} / \mathrm{cm}$ and from 22 to $28 \mathrm{mg} / \mathrm{L}$, respectively. The SEC and $\mathrm{Cl}^{-}$concentrations did not clearly exhibit a large vertical gradient of concentration. These results indicate that the $\mathrm{SEC}$ and $\mathrm{Cl}^{-}$concentrations in all the layers had high homogeneity. In particular, $\mathrm{Cl}^{-}$is a conservative ion, and the homogeneous distribution of $\mathrm{Cl}^{-}$concentrations in all the layers will facilitate the supply of groundwater from the sand and gravel layer to the aquitard; this hypothesis was confirmed by the contour lines of hydraulic head.

The contour lines of $\mathrm{NO}_{3}^{-}$concentrations observed on August 28, 2003, October 24, 2003, and December 28, 2003 are presented in Fig. 7. The chemical heterogeneity of $\mathrm{NO}_{3}{ }^{-}$in the aquitard has been clearly demonstrated. It is very interesting that the heterogeneity of $\mathrm{NO}_{3}{ }^{-}$in the aquitard was larger than that of $\mathrm{NO}_{3}{ }^{-}$in the sand and gravel layer. In the aquitard of transect $\mathrm{A}$, at a depth of $3.0 \mathrm{~m}$ and horizontal range of $6.0 \mathrm{~m}, \mathrm{NO}_{3}^{-}$varied from 27.8 to $2.9 \mathrm{mg} / \mathrm{L}$. On the other hand, at a depth of $3.5 \mathrm{~m}$, the $\mathrm{NO}_{3}{ }^{-}$concentrations were low and constant. Similarly, in the case of the aquitard of transect $\mathrm{B}$, at a depth $3.5 \mathrm{~m}$ and horizontal range of $6.0 \mathrm{~m}, \mathrm{NO}_{3}^{-}$varied from 28.6 to $1.8 \mathrm{mg} / \mathrm{L}$. Furthermore, the $\mathrm{NO}_{3}{ }^{-}$distributions at a depth of 3.5 $\mathrm{m}$ in transects $\mathrm{A}$ and $\mathrm{B}$ revealed complex lateral heterogeneity at the $4 \mathrm{~m} \times 6 \mathrm{~m}$ scale in the aquitard. It is evident that the chemical conditions can change significantly in these piezometers within lateral intervals in the aquiatrds that are as narrow as $2 \mathrm{~m}$. This result shows that it is difficult to identify the heterogeneity of $\mathrm{NO}_{3}{ }_{3}^{-}$concentrations of groundwater in an aquitard using a small number of piezometers. Hence, upscaling methodologies for the $\mathrm{NO}_{3}{ }^{-}$cycle models in an aquitard must be developed carefully. Piezometers were installed in the aquitard of transect $\mathrm{A}$ at a depth of $2.5 \mathrm{~m}$. However, the contour lines of hydraulic head indicate that the groundwater quality in these piezometers was more affected by the horizontal groundwater flow than that in case of the other piezometers installed in the aquitard. Hence, the piezometers were not considered for discussing the possible mechanisms for the heterogeneity of the $\mathrm{NO}_{3}{ }^{-}$distribution in aquitards at a few meter-scales.

In this study, the meter-scale lateral heterogeneity of the $\mathrm{NO}_{3}{ }^{-}$concentrations in the groundwater in the aquitard has been obtained, as described previously. The $\mathrm{NO}_{3}{ }^{-}$concentrations in the groundwater in the shallower regions of the aquitard, i.e., in the higher elevations of transect $A$, was particularly high. This result agree with the groundwater flow deduced from the contour lines of hydraulic head 

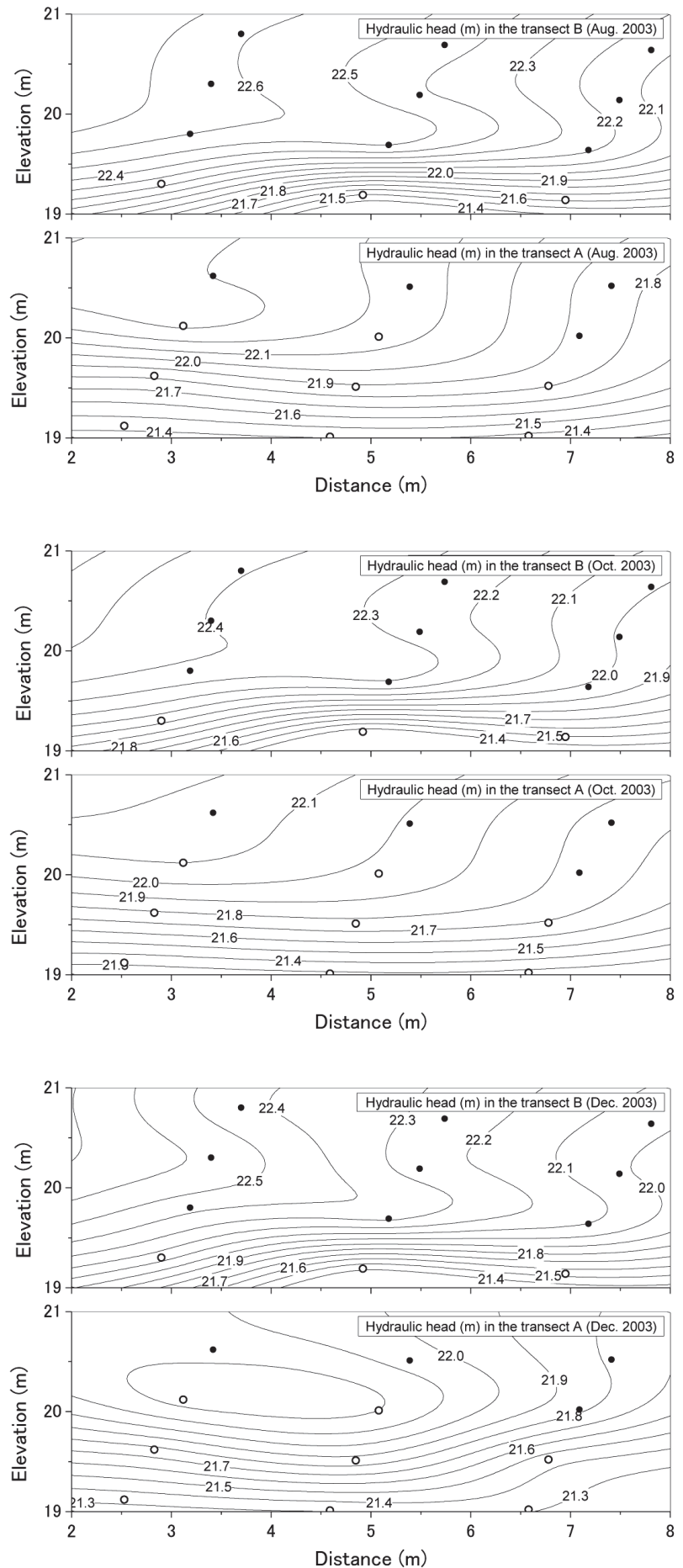

Fig. 4 Contour lines of hydraulic head (m) observed on August 28, 2003, October 24, 2003 and December 28, 2003 in piezometer nests along two transects. $\bullet$ : piezometers installed in the sand and gravel layer. $\bigcirc$ : piezometers installed in the silt and clay layer. 

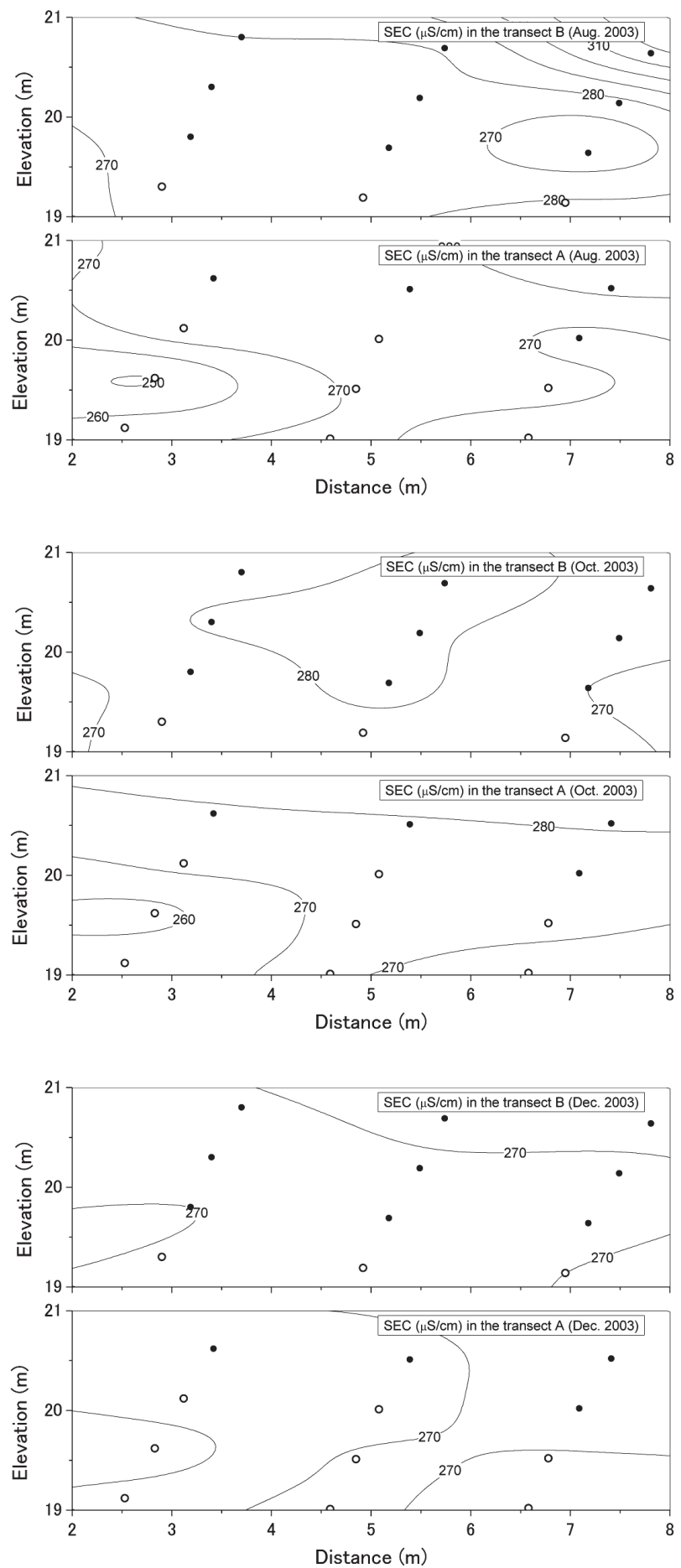

Fig. 5 Contour lines of SEC ( $\mu \mathrm{S} / \mathrm{cm}$ ) observed on August 28, 2003, October 24, 2003 and December 28, 2003 in piezometer nests along two transects. ๑: piezometers installed in the sand and gravel layer. $\bigcirc$ : piezometers installed in the silt and clay layer. 

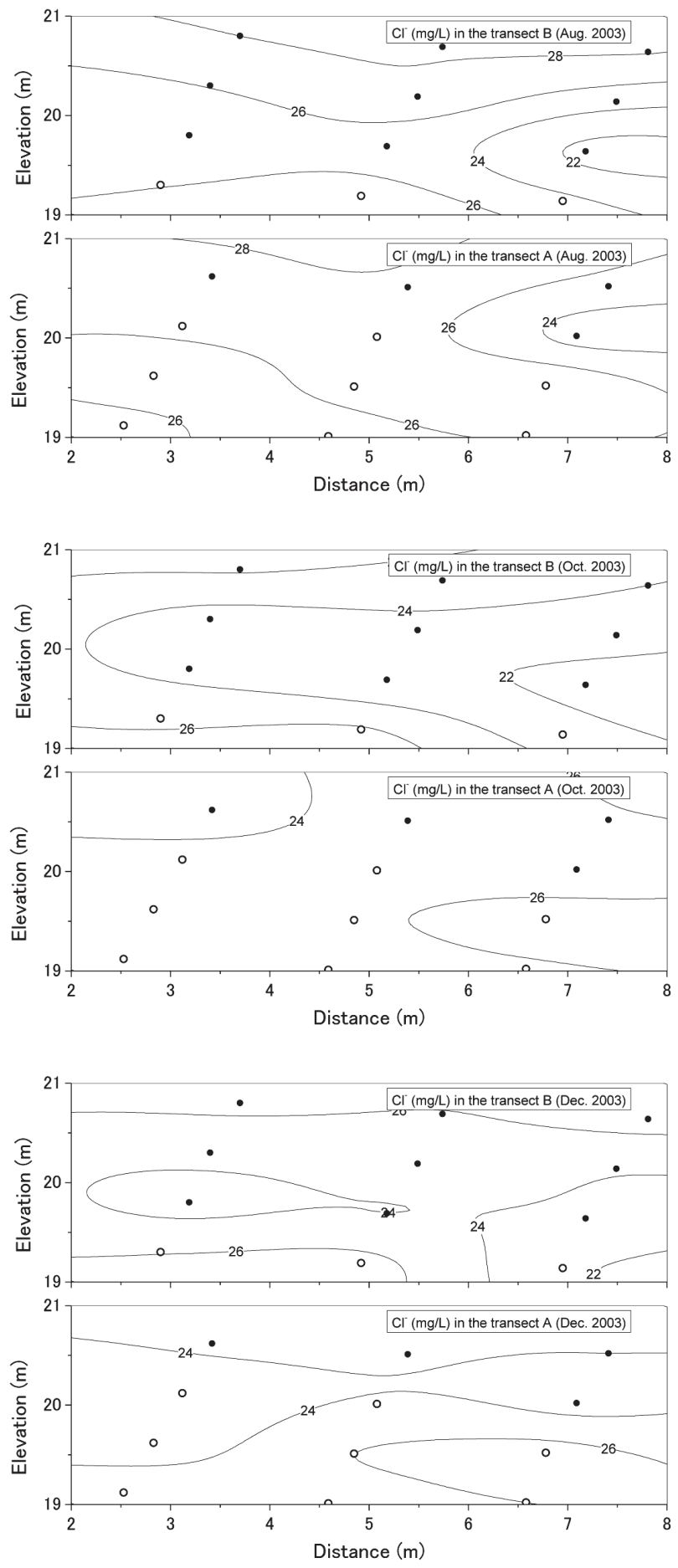

Fig. 6 Contour lines of $\mathrm{Cl}^{-}$concentrations ( $\mathrm{mg} / \mathrm{L}$ ) observed on August 28, 2003, October 24, 2003 and December 28, 2003 in piezometer nests along two transects. $\bullet$ : piezometers installed in the sand and gravel layer. $\bigcirc$ : piezometers installed in the silt and clay layer. 

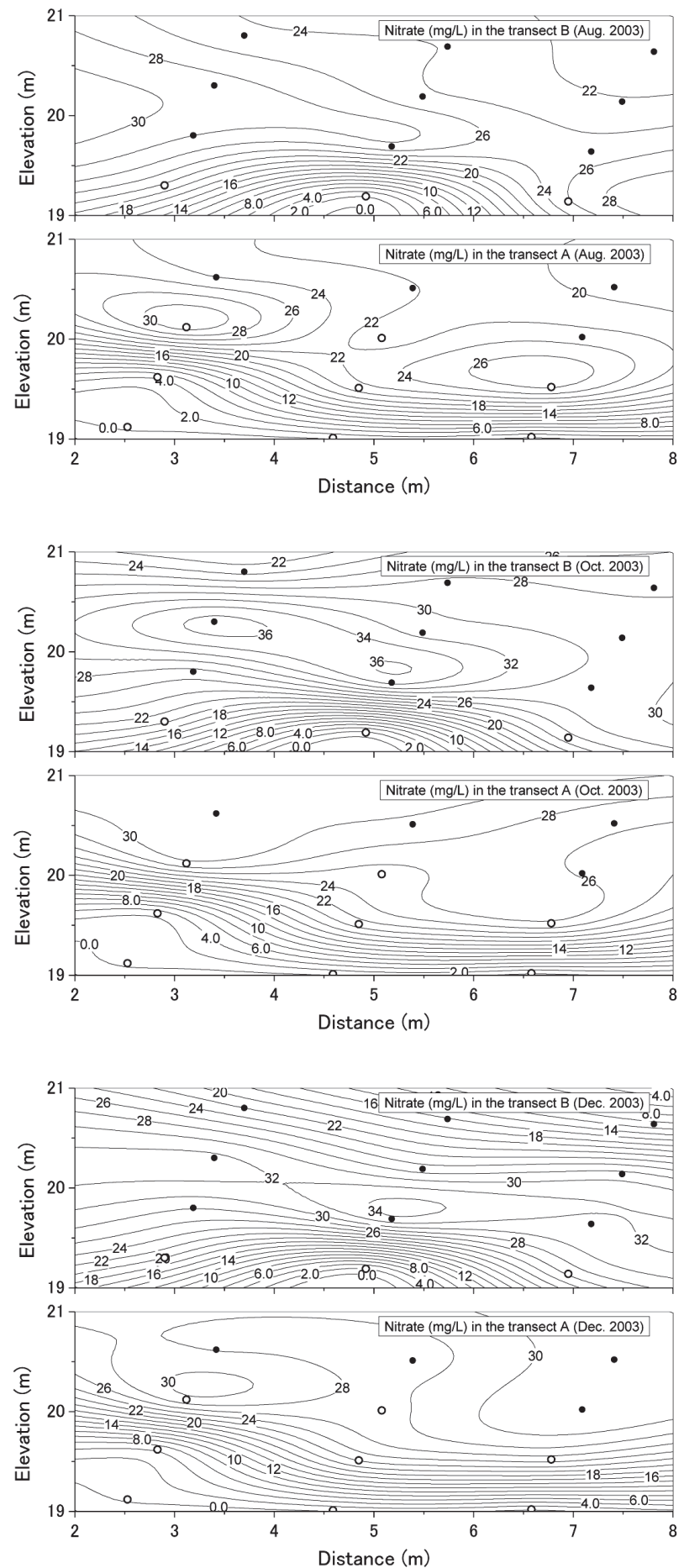

Fig. 7 Contour lines of $\mathrm{NO}_{3}{ }^{-}$concentrations (mg/L) observed on August 28, 2003, October 24, 2003 and December 28, 2003 in piezometer nests along two transects. $\bullet$ : piezometers installed in the sand and gravel layer. $\bigcirc$ : piezometers installed in the silt and clay layer. 
and $\mathrm{Cl}^{-}$concentrations. Hence, it can be deduced that $\mathrm{NO}_{3}{ }^{-}$in the groundwater in the aquitard was supplied by the groundwater in the sand and gravel layer. Further, the low $\mathrm{NO}_{3}{ }^{-}$concentrations observed in the groundwater in the aquitard at certain depths may be because of biochemical reaction processes such as in-situ denitrification or spatial variability of $\mathrm{NO}_{3}{ }^{-}$transport from the sand and gravel layer to the aquitard.

Figs. 8-10 shows the contour lines of DO, $\mathrm{SO}_{4}{ }^{2-}$, and $\mathrm{HCO}_{3}{ }^{-}$concentration observed on August 28, 2003, October 24, 2003, and December 28, 2003 at the study plot. The DO concentrations ranged from 1 to $8 \mathrm{mg} / \mathrm{L}$ in all the layers of both transects. Low DO concentrations ranging from 1 to $3 \mathrm{mg} / \mathrm{L}$ were observed in the piezometers with low $\mathrm{NO}_{3}{ }^{-}$concentrations at the depth of $3.5 \mathrm{~m}$ in the aquitard in both transects. Denitrification will probably occur at concentrations below $1 \mathrm{mg} / \mathrm{L}$ and may even occur at concentrations below 2 $\mathrm{mg} / \mathrm{L}$ (Buss et al., 2005). Considering the fact that the DO concentrations were measured in an open container, where there is an air-water interface, that value of the in situ DO concentrations must be lower than that of the measured DO concentrations. Thus, denitrification may occur in an aquitard with low DO concentrations. The $\mathrm{SO}_{4}{ }^{2-}$ concentrations ranged from 40 to $60 \mathrm{mg} / \mathrm{L}$ in transect $\mathrm{A}$ and from 40 to $55 \mathrm{mg} / \mathrm{L}$ in transect $\mathrm{B}$. The highest $\mathrm{SO}_{4}{ }^{2-}$ concentrations were obtained at a $3.5 \mathrm{~m}$ depth in the aquitard of transect $\mathrm{A}$. The distribution of $\mathrm{SO}_{4}{ }^{2-}$ concentrations in groundwater was inversely proportional to that of $\mathrm{NO}_{3}^{-}$concentrations -an approximate increase of $5 \mathrm{mg} / \mathrm{L}(0.052 \mathrm{mM})$ of $\mathrm{SO}_{4}{ }^{2-}$ was accompanied by a decrease of $30 \mathrm{mg} / \mathrm{L}$ (0.484 mM) of $\mathrm{NO}_{3}^{-}$. The $\mathrm{HCO}_{3}^{-}$concentrations ranged from approximately 10 to $40 \mathrm{mg} / \mathrm{L}$ in both transects. High $\mathrm{HCO}_{3}{ }^{-}$concentrations ranging from 25 to $40 \mathrm{mg} / \mathrm{L}$ were observed in the piezometers with low $\mathrm{NO}_{3}{ }^{-}$concentrations. This indicates an approximate increase of $15 \mathrm{mg} / \mathrm{L}(0.246 \mathrm{mM})$ of $\mathrm{HCO}_{3}{ }^{-}$with a decrease of $30 \mathrm{mg} / \mathrm{L}(0.484 \mathrm{mM})$ of $\mathrm{NO}_{3}{ }^{-}$. The increase in $\mathrm{SO}_{4}{ }^{2-}$ and $\mathrm{HCO}_{3}{ }^{-}$concentrations along with the decrease in $\mathrm{NO}_{3}{ }^{-}$concentrations in the aquitard can be considered as evidence of $\mathrm{NO}_{3}{ }^{-}$reduction, or in other words, denitrification coupled with pyrite and organic carbon oxidation in groundwater (e.g. Postma et al., 1991; Aravena and Robertson, 1998; Ioka and Tase, 2004a). The corresponding reactions are as follows:

$$
\begin{aligned}
& 5 \mathrm{FeS}_{2}+6 \mathrm{NO}_{3}{ }^{-}+2 \mathrm{H}_{2} \mathrm{O} \rightarrow \\
& 3 \mathrm{~N}_{2}+5 \mathrm{FeOOH}+4 \mathrm{SO}_{4}{ }^{2-}+2 \mathrm{H}^{+} \\
& 5 \mathrm{C}+2 \mathrm{H}_{2} \mathrm{O}+4 \mathrm{NO}_{3}{ }^{-} \rightarrow 2 \mathrm{~N}_{2}+4 \mathrm{HCO}_{3}{ }^{-}+\mathrm{CO}_{2}
\end{aligned}
$$

Considering the chemical mass balance associated with reactions 1 and 2 and examining the inversely proportional relationships between the increase of $\mathrm{SO}_{4}{ }^{2-}$ and $\mathrm{HCO}_{3}{ }^{-}$concentrations and the decrease of $\mathrm{NO}_{3}{ }^{-}$concentrations described above, the simple mass balances indicate that approximately $67 \%$ of $\mathrm{NO}_{3}{ }^{-}$lost was due to denitirification. Therefore, the lateral heterogeneity of the $\mathrm{NO}_{3}{ }^{-}$concentrations in the groundwater in the aquitard at the study plot probably indicates that denitrification and other processes, e.g., spatial variability of $\mathrm{NO}_{3}{ }^{-}$transport, occur in aquitards. This study indicates that it is necessary to conduct further researches on the denitrification processes in the aquitard to clarify this completely. In particular, the occurrence and rate of denitrification must be investigated; further, the compositions and bioavailability of organic carbon electron donors must be examined, and the nature of biotic and abiotic autotrophic denitrification reactions involving sulfur electron donors must be studied. In addition, mechanism of spatial variability of $\mathrm{NO}_{3}{ }^{-}$transport processes in the aquitard must be investigated. 

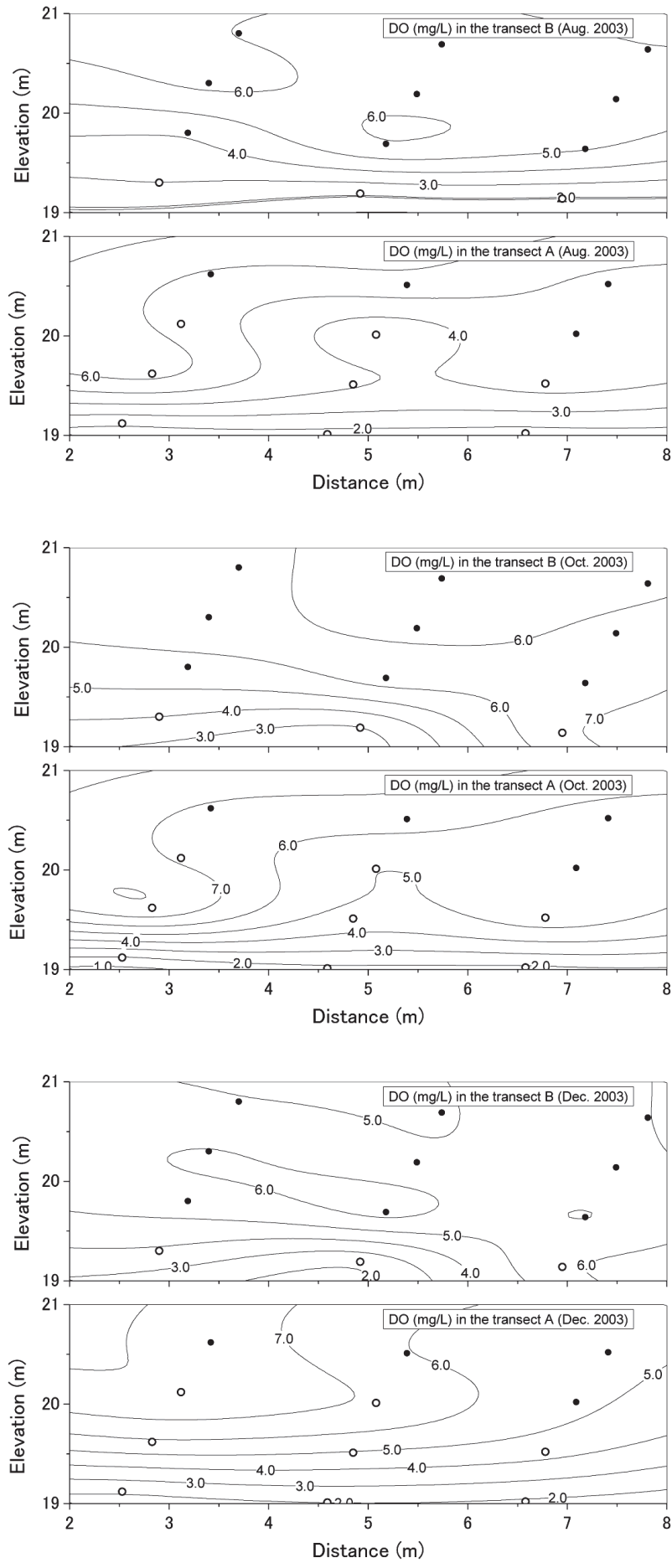

Fig. 8 Contour lines of DO concentrations (mg/L) observed on August 28, 2003, October 24, 2003 and December 28, 2003 in piezometer nests along two transects. $\bullet$ : piezometers installed in the sand and gravel layer. $\bigcirc$ : piezometers installed in the silt and clay layer. 
IOKA and TASE
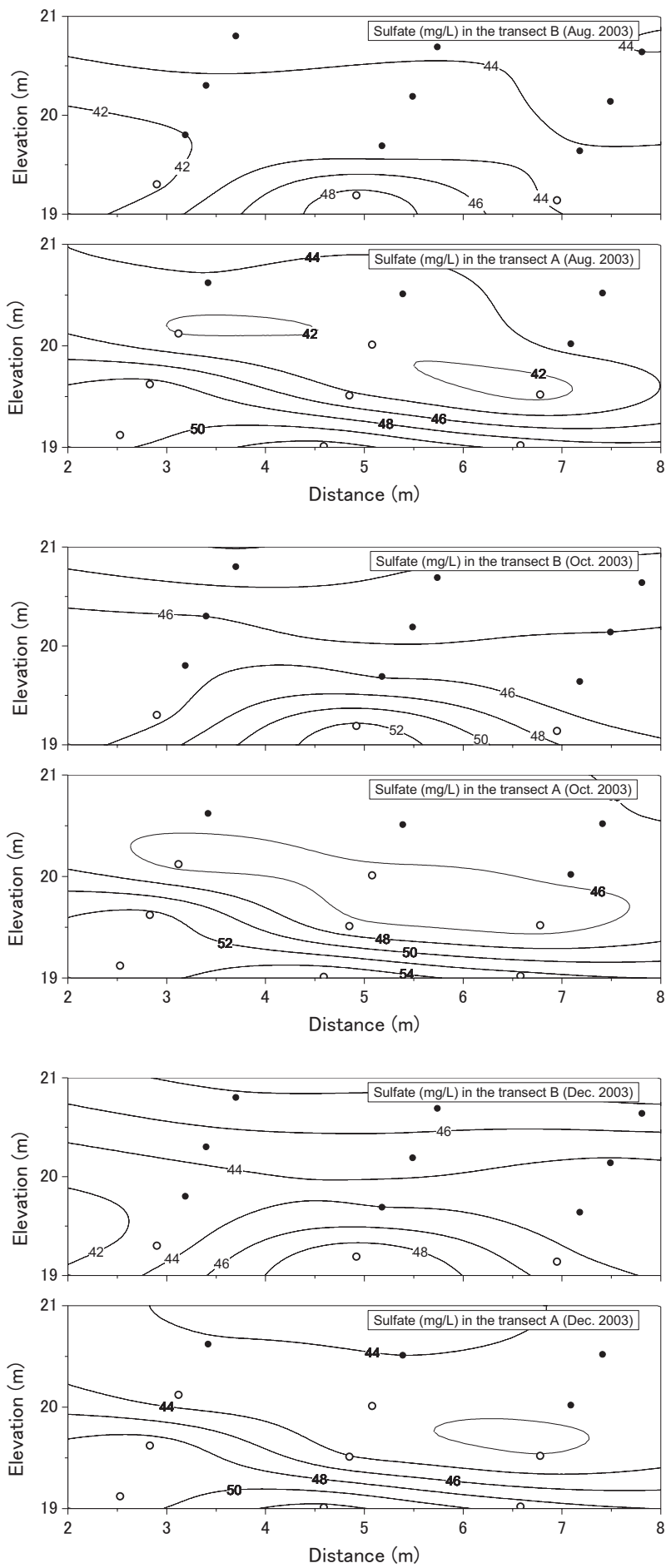

Fig. 9 Contour lines of $\mathrm{SO}_{4}^{2-}$ concentrations (mg/L) observed on August 28, 2003, October 24, 2003 and December 28, 2003 in piezometer nests along two transects. $\bullet$ : piezometers installed in the sand and gravel layer. $\bigcirc$ : piezometers installed in the silt and clay layer. 

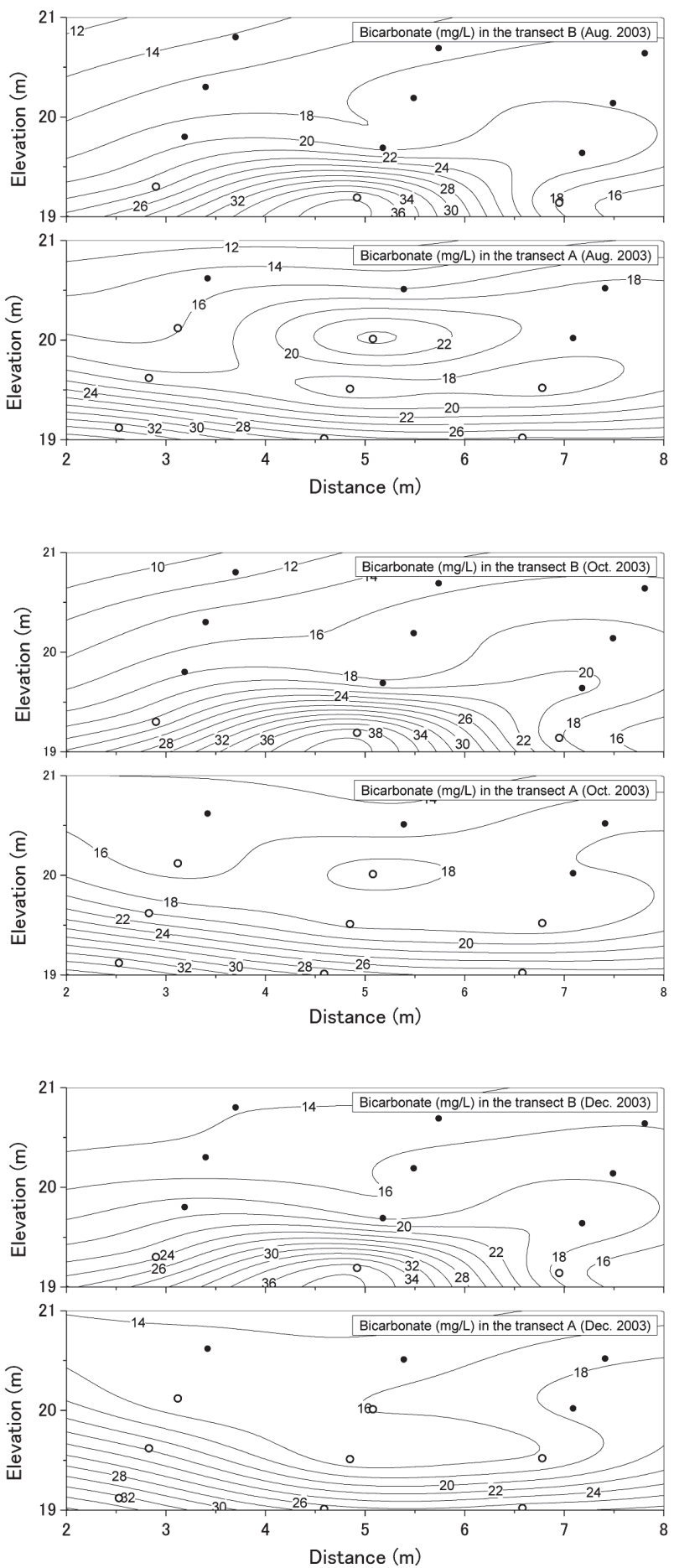

Fig. 10 Contour lines of $\mathrm{HCO}_{3}{ }^{-}$concentrations ( $\mathrm{mg} / \mathrm{L}$ ) observed on August 28, 2003, October 24, 2003 and December 28, 2003 in piezometer nests along two transects. $\bullet$ : piezometers installed in the sand and gravel layer. $\bigcirc$ : piezometers installed in the silt and clay layer. 


\section{Conclusion}

The lateral heterogeneity of $\mathrm{NO}_{3}{ }^{-}$concentrations of groundwater in an aquitard at Tsukuba upland was investigated using 11 piezometers over an area of $4 \mathrm{~m} \times 6 \mathrm{~m}$ and to a maximum depth of $\sim 3.5 \mathrm{~m}$ below the ground surface. $\mathrm{NO}_{3}{ }^{-}$in the aquitard was supplied from $\mathrm{NO}_{3}{ }^{-}$in the sand and gravel layer by groundwater flow. This study demonstrated that relatively large changes in $\mathrm{NO}_{3}{ }^{-}$concentrations-from approximately 30 to $1 \mathrm{mg} / \mathrm{L}$-occur on a lateral axis in an aquitard as narrow as $2 \mathrm{~m}$. We have suggested mechanisms responsible for the heterogeneity of $\mathrm{NO}_{3}{ }^{-}$concentrations in aquitards; denitrification processes and other processes such as spatial variability of the $\mathrm{NO}_{3}{ }^{-}$transport process; the mechanism is related to natural $\mathrm{NO}_{3}{ }^{-}$attenuation processes. However, presently, we do not have any field data to test these hypotheses and consider the accumulation of such data as important information for future research. In addition, the heterogeneity of $\mathrm{NO}_{3}{ }^{-}$concentrations indicated that the difficulties in developing an upscaling methodology for the $\mathrm{NO}_{3}{ }^{-}$cycle models in groundwater.

\section{Acknowledgements}

This work was partly supported by the Sasakawa Scientific Research Grant from The Japan Science Society.

\section{References}

Aravena, R.A. and Robertson, W.D. (1998): Use of multiple isotope tracers to evaluate denitirification in ground water: study of nitrate from a large-flux septic system plume. Ground Water, 36, 975-982.

Back, W. (1986): Role of aquitards in hydrogeochemical systems: a synopsis. Appl. Geochem., 1,
427-437.

Böhlke, J.K. and Denver, J.M. (1995): Combined use of groundwater dating, chemical, and isotopic analyses to resolve the history and fate of nitrate contamination in two agricultural watersheds, Atlantic coastal plain, Maryland. Water Resour. Res., 31, 2319-2339.

Böhlke, J.K., Wanty, R., Tuttle, M., Delin, G. and Landon, M. (2002): Denitrification in the recharge area and discharge area of a transient agricultural nitrate plume in a glacial outwash sand aquifer, Minnesota. Water Resour. Res., 38 , doi:10.1029/2001WR000663.

Buss, S.R., Rivett, M.O., Morgan, P. and Bemmet, C.D. (2005): Attenuation of nitrate in the sub-surface environment. Science Report SC030155/SR2, Environment Agency, 100p.

Eidem, J.M., Simpkins, W.W. and Burkart, M.R. (1999): Geology, groundwater flow, and water quality in the Walnut Creek watershed. J. Environ. Qual., 28, 30-69.

Ernstsen, V. (1996): Reduction of nitrate by $\mathrm{Fe}^{2+}$ in clay minerals. Clay Clay Miner., 44, 599-608.

Ernstsen, V., Binnerup, S.J. and Sorensen, J. (1998): Reduction of nitrate in clayey subsoils controlled by geochemical and microbial barriers. Geomicrobiol.J., 7, 53-66.

Fujikawa, J.I. and Hendry, M.J. (1991): Denitrification in clayey till. J. Hydrol., 127, 337-348.

Hansen, J.R., Ernstsen, V., Refsgaard, J.C. and Hansen, S. (2008): Field scale heterogeneity of redox conditions in till-upscaling to a catchment nitrate model. Hydrogeol. J., 16, 1251-1266.

Harrington, G.A. and Hendry, M.J. (2005): Chemical heterogeneity in diffusion-dominated aquitards. Water Resour. Res., 41, doi:10.1029/ 2004WR003928

Hvorslev, M.J. (1951): Time lag and soil permeability in groundwater observations. Bull. 36. Waterways Exper. Sta. Corps of Engrs, U.S. Army, Vicksburg, 
Mississippi, pp. 1-50.

Ioka, S. and Tase, N. (2004a): The role of silt and clay layer on nitrate concentration in groundwater-hydraulic barrier or biochemical barrier. $J$. Groundwater Hydrol., 46, 37-50. (in Japanese with English abstract)

Ioka, S. and Tase, N. (2004b): Nitrate reduction zone in groundwater at a slope-wetland plot in Tsukuba upland, Ibaraki Prefecture. J. Groundwater Hydrol., 46, 131-144. (in Japanese with English abstract)

Jørgensen, P.R., Urup, J., Helstrup, T., Jensen, M.B., Eiland, F. and Vinther, F.P. (2004): Transport and reduction of nitrate in clayey till underneath forest and arable land. J. Contam. Hydrol., 73, 207-226.

Lei, P. and Tase, N. (1986): Movement of chloride in clayey soil. J. Groundwater Hydrol., 28, 63-71. (in Japanese with English abstract)

McMahon, P.B., Böhlke, J.K. and Bruce, B.W. (1999): Denitrification in marine shales in northern Colorado. Water Resour. Res., 35, 1629-1642.

McMahon, P.B. (2001): Aquifer/aquitard interfaces: mixing zones that enhance biogeochemical reactions. Hydrogeol. J., 9, 34-43.

Nielsen, G.L. and Nielsen, D.M. (2007): Preparing sampling points for sampling: purging methods. In: Nielsen, G.L. and Nielsen, D.M. (Eds.), The essential handbook of ground-water sampling, CRC Press, 99-130.

Otero, N., Torrentó, C., Soler, A., Menció, A. and Mas-Pla, J. (2009): Monitoring groundwater nitrate attenuation in a regional system coupling hydrogeology with multi-isotope methods: The case of Plana de Vic (Osona, Spain). Agri. Ecosys. Environ., 133, 103-113.

Ponzini, G., Crost, G. and Giudici, M. (1989): The hydrogeological role of an aquitard in preventing drinking water well contamination: a case study. Environ. Health Pers., 93, 77-95.
Postma, D., Bolsen, C., Kristiansen, H. and Larsen, F. (1991): Nitrate reduction in an unconfined sandy aquifer: water chemistry, reduction processes, and geochemical modeling. Water Resour. Res., 27, 2027-2045.

Reddy, A.G.S., Kumar, K.N., Rao, D.S. and Rao, S.S. (2009): Assessment of nitrate contamination due to groundwater pollution in north eastern part of Anantapur District. Environ. Monit. Assess., 148, 463-476.

Rodvang, S.J. and Simpkins, W.W. (2001): Agricultural contaminants in quaternary aquitards: a review of occurrence and fate in North America. Hydrogeol. J., 9, 44-59.

Robertson, W.D., Russell, B.M. and Cherry, J.A. (1996): Attenuation of nitrate in aquitard sediments of southern Ontario. J. Hydrol., 180, 267-281.

Rudolph, D.L., Cherry, J.A. and Farvolden, R.N. (1991): Groundwater flow and solute transport in fractured lacustrine clay near Mexico City. Water Resour. Res., 27, 2187-2201.

Tesoriero, A.J., Liebscher, H. and Cox, S.E. (2000): Mechanism and rate of denitrification in an agricultural watershed: electron and mass balance along groundwater flow paths. Water Resour. Res., 36, 1545-1559.

Tesoriero, A.J., Saad, D.A., Burow, K.R., Frick, E.A., Puckett, L.J. and Barbash, J.E. (2007): Linking ground-water age and chemistry data along flow paths: implications for trends and transformations of nitrate and pesticide. J. Contam. Hydrol., 94, 139-155.

Unozawa, A. (1988): Each explanation of geology. In: Explanation text of the environmental geology map of the Tsukuba science city and its surroundings (ed. by A. Unozawa, I. Isobe, H. Endo, Y. Taguchi, S. Nagai, T. Ishii, T. Aihara, and S. Oka), 31-59. Geological Survey of Japan.

Umezawa, Y., Hosono, T., Onodera, S., Siringan, F., 
Buapeng, S., Delinom, R., Yoshimizu, C., Tayasu, I., Nagata, T. and Taniguchi, M. (2009): Erratum to 'Sources of nitrate and ammonium contamination in groundwater under developing Asian megacities'. Sci. Total. Environ., 407, 3219-3231.

Van Stempvoort, D.R. and van der Kamp, G. (2003): Modeling the hydrogeochemistry of aquitards using minimally disturbed samples in radial diffusion cells. Appl. Geochem., 18, 551-565.

Yasuhara, M., Marui, A., Fuseya, M. and Ishii, T. (1991): Physical properties of the Joso Clay in the Tsukuba upland from hydrological point of view. Geograph. Rev. of Japan, 64A-10, 719-727. (in Japanese with English abstract) Yuita, K., Noda, T., Kihou, N., Hashimoto, N. and Kawamitsu, K. (2002): Construction and utilization on the tracer experiment fields for the chemical elements from the soil surface to the groundwater system. Jpn. J. Soil Sci. Plant Nutr., 73, 57-63. (in Japanese)

(原稿受付：2010年 9 月 7 日)

(原稿受理：2011年 5 月23日)

この論文に対する「討論」を2012年 5 月30日ま で受け付けます。 


\title{
難透水層中地下水における $\mathrm{NO}_{3}{ }^{-}$濃度の メートルスケールの不均質性
}

\author{
井岡 聖一郎・田瀬 則雄
}

\begin{abstract}
要 旨
世界中に打いて地下水の長期的な保全は，部分的に難透水層に依存している。 なぜなら，難透水層は，自然・人為起源物質の移行に影響を与えるからである。 そのため，難透水層中の溶存物質の分布，輸送，そして挙動を制御している過程 を理解することが重要である。さらに，近年では地下水中に打ける人為的な窒素 循環量が増大し，関心を集めている。そのため，難透水層中に打ける地下水の $\mathrm{NO}_{3}$-の挙動が検証されなければならない。私たちは，筑波台地において，数メ一 トルスケールで難透水層中 $(4 \mathrm{~m} \times 6 \mathrm{~m})$ の $\mathrm{NO}_{3}$ - 濃度の水平的な分布を調査し, その不均質性をもたらす機構を明らかにすることを試みた。なお，このような研 究は私たちが知っている限り最初の研究である。高密度の観測は，ピエゾメータ を用いて実施し，複雑な水平的な $\mathrm{NO}_{3}{ }^{-}$の不均質性を明らかにした。ピエゾメー タから採取された地下水の大きな $\mathrm{NO}_{3}$ - 濃度の差異は，わずか $2 \mathrm{~m}$ の範囲内にお いて認められた。本観測で明らかになった $\mathrm{NO}_{3}$ - 濃度の不均質性をもたらす要因 は，確定することはできなかったがおそらく脱窒や $\mathrm{NO}_{3}{ }^{-}$輸送過程の不均一性に よるものであると推察される。本研究は，難透水層中地下水の $\mathrm{NO}_{3}-$ 濃度の不均 質性を数メートルスケールで示した初めての研究であり，難透水層中における $\mathrm{NO}_{3}$-の自然減衰に対して新たな視点を与えるものである。また同時に，少ない 本数のピエゾメータの観測から得られた結果を用いて, $\mathrm{NO}_{3}{ }^{-}$の自然減衰帯の広 域評価を実施するのは困難であることが示唆された。
\end{abstract}

キーワード：不均質性， $\mathrm{NO}_{3}^{-}$，地下水，難透水層 